Суд не должен ориентироваться только на исследование предъявленного обвинения и, даже при его внешней убедительности, демонстрировать недоверие к заявлениям и аргументам стороны защиты. В подобных случаях неизбежно возникают сомнения в беспристрастности суда.

ЕСПЧ справедливо обращает внимание на недопустимость игнорирования ходатайств стороны защиты о приобщении новых материалов к уголовному делу или допросе определенных лиц в качестве свидетелей и отказе суда в этом, даже тогда, когда по формальным признакам такие доказательства признаются недопустимыми, не отвечающими требованию действующего законодательства, без непосредственного исследования содержания их информации, которая предлагается защитой. В этом случае суд лишается возможности проанализировать аргументы ее оспаривания и оценки при принятии итогового решения. Происходит нарушение требования о всестороннем, полном и объективном непосредственном исследовании представленных стороной защиты доказательств в ходе судебного следствия, что вызывает сомнения в справедливости и объективности судебного процесса [6].

Исходя из изложенного, очевидно, что ч. 1 ст. 252 УПК РФ нуждается в существенном редакционном изменении. Ее основой должно стать положение о том, что судебное разбирательство проводится с целью непосредственного исследования позиций сторон, представленных ими доказательств, анализа доводов и аргументов.

$$
* * *
$$

1. Власова С.В., Балалаева М.В. Современный правовой формат судебного следствия // Проблемы правоохранительной деятельности. № 3. 2016. С.59.

2. См. подробнее: Постановление Пленума Верховного Суда РФ № 21 от 27 июня 2013 г. «О применении судами общей юрисдикции Конвенции о защите прав человека и основных свобод от 4 ноября 1950 г. и Протоколов к ней».

3. Мезинов Д.А. О проблемах реализации начала непосредственности судебного разбирательства в уголовном судопроизводстве // Вестник Омского университета. Серия «Право». 2008. № 4 (17). С.178.

4. См. Постановление ЕСПЧ по делу «Ирландия против Соединенного Королевства» (Ireland v. United Kingdom) от 18 января 1978 г. Доступ из справ.- правовой системы «КонсультантПлюс».

5. Допустимость доказательств в уголовном процессе: стандарты ЕСПЧ и судебная практика. Научнопрактическое пособие. М. 2016. Издательство: «Право». С.204-205.

6. См. постановление ЕСПЧ по делу «Видал (Vidal) против Бельгии» от 22 апреля 1992 г. № 12351/86, п. 18, 20. Доступ из справ. - правовой системы «КонсультантПлюс».

\title{
Бялт В.С., Чимаров С.Ю. \\ Служебная проверка как стадия дисциплинарного производства на государственной гражданской службе Российской Федерации
}

Санкт-Петербургский университет МВД России (Россия, Санкт-Петербург)

doi: 10.18411/trnio-10-2021-116

\section{Аннотация}

Статья посвящена исследованию актуальных проблем в сфере нормативного правового регулирования и правоприменительной практики при привлечении государственных гражданских служащих к дисциплинарной ответственности. Авторами сформулировано и обосновано предложение, связанное с необходимостью принятия нормативного правового акта, посвященного регулированию правоотношений при проведении служебной проверки в отношении государственных гражданских служащих. Ключевые слова: служебная проверка, дисциплинарное производство, дисциплинарная ответственность, государственная гражданская служба.

Abstract

The article is devoted to the study of current problems in the field of regulatory legal regulation and law enforcement practice in bringing state civil servants to disciplinary 
responsibility. The authors formulated and justified a proposal related to the need to adopt a regulatory legal act on the regulation of legal relations during the performance of an official audit in relation to state civil servants.

Keywords: internal audit, disciplinary proceedings, disciplinary responsibility, state civil service.

Дисциплинарные правоотношения государственных гражданских служащих регулируются федеральным законом от 27 июля 2004 года № 79-Ф3 «О государственной гражданской службе Российской Федерации» (глава 12). В этой главе даются определения служебной дисциплины на государственной гражданской службе, дисциплинарного проступка, приводится перечень дисциплинарных взысканий, которые могут быть применены в отношении государственных гражданских служащих, описывается порядок применения и снятия дисциплинарного взыскания, а также порядок проведения служебной проверки.

К сожалению, указанный нормативный правовой акт не устанавливает конкретного перечня стадий производства по привлечению государственных гражданских слушателей к дисциплинарной ответственности, как и не дает официального определения понятия дисциплинарного производства. Попытаемся путем анализа научной литературы и правовых норм федерального закона «О государственной гражданской службе Российской Федерации» сформулировать обозначенное понятие и предложить свой вариант перечня стадий дисциплинарного производства.

В научных кругах приводятся различные определения дисциплинарного производства. Так, Д.Н. Бахрах определяет дисциплинарное производство «как регулируемую правовыми нормами деятельность субъектов дисциплинарной власти по применению дисциплинарных взысканий» [11, c. 589]. П. С. Бутов полагает, что дисциплинарное производство представляет собой установленный законодательством порядок и формы осуществления юридически значимых процессуальных действий по применению дисциплинарного взыскания в связи с совершением соответствующего дисциплинарного проступка, а также формы результатов осуществления указанных действий [12, с. 155]. Ю. Н. Туганов считает, что дисциплинарное производство - это процедура применения мер дисциплинарной ответственности [18, с. 173]. По мнению Ю. С. Адушкина под дисциплинарным производством принято понимать совокупность юридических норм, регулирующих общественные отношения в связи с правоприменительной деятельностью по решению вопросов дисциплинарной ответственности за допущенное дисциплинарное правонарушение [10, с. 42].

По нашему мнению, дисциплинарное производство представляет собой нормативно урегулированную деятельность полномочного субъекта (представителя нанимателя) по рассмотрению и разрешению дел о дисциплинарных проступках, заключающуюся в совокупности процессуальных действий по применению к подчиненным по службе мер дисциплинарной ответственности [13, с. 120].

В отношении определения и количества стадий производства по делам о привлечении к дисциплинарной ответственности среди ученых также имеются различные подходы. Так, по мнению А. А. Абрамовой, дисциплинарное производство включает в себя следующие стадии: выявление дисциплинарного правонарушения и подготовка дела, рассмотрение дела и наложение взыскания, прекращение процесса [9, с. 138]. Д. Н. Бахрах различает такие стадии как служебное разбирательство, рассмотрение дисциплинарного дела, пересмотр дела, исполнение наложенного взыскания [11, с. 589]. В. М. Лебедев разделяет дисциплинарное производство на четыре обязательные и две факультативные стадии. К первым он относит возбуждение дисциплинарного преследования, подготовку материалов к рассмотрению дела, рассмотрение дела и выбор меры воздействия, издание и исполнение приказа о взыскании. В числе факультативных стадий называются обжалование взыскания, а также прекращение дисциплинарного воздействия в результате пересмотра дела [15, с. 125-128]. О.Э. Лейст полагает, что законодатель достаточно четко разграничивает 
для дисциплинарной ответственности «такие стадии, как возбуждение дисциплинарного дела, проверка, подготовка решения, его вынесение - (право обжалования)» [16, с. 137]. Б. И. Жерлицын выделяет пять стадий дисциплинарного производства: возбуждение дисциплинарного преследования, рассмотрение дела, наложение, обжалование и исполнение взыскания [14, с. 28-33].

Мы полагаем, что применительно к государственным гражданским служащим статьи 58 и 59 федерального закона «О государственной гражданской службе Российской Федерации» позволяют выделить следующие стадии дисциплинарного производства: возбуждение дисциплинарного производства, проведение служебной проверки, принятие решения, исполнение принятого решения и пересмотр решения о дисциплинарном взыскании. Причем необходимо пояснить, что первые четыре стадии являются обязательными, а последняя - пересмотр, является факультативной, поскольку государственный гражданский служащий не во всех случаях наложения взыскания станет его обжаловать.

Рассмотрим подробнее стадию проведения служебной проверки. Порядку проведения служебной проверки в отношении государственного гражданского служащего посвящена всего лишь одна статья указанного закона (статья 59). В ней перечислены следующие моменты: что должно быть установлено при проведении служебной проверки, кто не может участвовать в проведении служебной проверки, срок проведения служебной проверки, права гражданского служащего, в отношении которого проводится служебная проверка, что необходимо указать в письменном заключении по результатам служебной проверки.

Однако хотелось бы отметить, что правовые нормы данной статьи не содержат, к примеру, таких, на наш взгляд, существенных моментов, как основание и повод для проведения служебной проверки, срок, в течение которого должна быть назначена служебная проверка, содержание приказа о назначении служебной проверки, права и обязанности, гражданского служащего, проводящего служебную проверку. По нашему мнению, данное обстоятельство не способствует реализации принципов законности и справедливости при привлечении государственных гражданских служащих к дисциплинарной ответственности. С нашей точки зрения, все же следует более тщательным образом регламентировать порядок проведения служебной проверки в отношении государственных гражданских служащих, поскольку результаты данной проверки в конечном итоге могут способствовать ограничению прав гражданских служащих $[17$, c. 18$]$.

Необходимо указать, что на сегодняшний день различные моменты, связанные с прохождением гражданскими служащими государственной службы, регулируются отдельными нормативными правовыми актами, число которых довольно значительно [1; $2 ; 3]$.

Сообразно с этим, мы полагаем, что было бы вполне логично и обосновано принять новый нормативный правовой акт, утверждающий Инструкцию о порядке организации и проведения служебных проверок в отношении государственных гражданских служащих, тем более что для некоторых категорий государственных служащих правоотношения, связанные с порядком проведения служебных проверок, регулируются отдельными нормативными правовыми актами, специально посвященными вопросам организации и проведения служебных проверок $[4 ; 5 ; 6 ; 7 ; 8]$.

$$
* * *
$$

1. Указ Президента Российской Федерации от 1 февраля 2005 года № 110 «О проведении аттестации государственных гражданских служащих Российской Федерации» // С3 РФ. 2005. № 6. Ст. 437.

2. Указ Президента Российской Федерации от 1 февраля 2005 года № 111 «О порядке сдачи квалификационного экзамена государственными гражданскими служащими Российской Федерации и оценки их знаний, навыков и умений (профессионального уровня)» // СЗ РФ. 2005. № 6. Ст. 438.

3. Указ Президента Российской Федерации от 1 февраля 2005 года № 112 «О конкурсе на замещение вакантной должности государственной гражданской службы Российской Федерации» // С3 РФ. 2005. № 6. Ст. 439. 
4. Приказ МВД России от 26 марта 2013 года № 161 «Об утверждении порядка проведения служебной проверки в органах, организациях и подразделениях Министерства внутренних дел Российской Федерации» // Российская газета, 2013, 14 июня.

5. Приказ ФСИН России от 12 апреля 2012 года № 198 «Об утверждении Инструкции об организации и проведения служебных проверок в учреждениях и органах уголовно-исполнительной системы» // Российская газета, 2012, 7 сентября.

6. Приказ Генпрокуратуры России от 28 апреля 2016 года № 255 «Об утверждении Инструкции о порядке проведения служебных проверок в отношении прокурорских работников органов и организаций прокуратуры Российской Федерации» // Законность. 2016. № 7.

7. Приказ ФНС России от 22 августа 2011 года № ММВ-7-4/507 «Об утверждении Инструкции об организации проведения служебной проверки в Федеральной налоговой службе» // Российская газета, 2011, 5 октября.

8. Приказ ФТС России от 2 августа 2012 года № 1557 «Об утверждении Инструкции об организации и о проведении служебной проверки в таможенных органах Российской Федерации» // Российская газета, 2012 , 24 октября.

9. Абрамова А. А. Дисциплина труда в СССР (правовые вопросы). - М., 1969.

10. Адушкин Ю. С. Дисциплинарное производство в СССР. - Саратов, 1986.

11. Бахрах Д. Н. Административное право России: учебник. - М., 2001.

12. Бутов П. С. Совершенствование материальных и процедурно-процессуальных норм о применении дисциплинарной ответственности работников по трудовому праву Российской Федерации: Дисс. .... канд. юрид. наук. - Челябинск, 2005.

13. Бялт В. С., Чимаров С. Ю. Порядок применения мер поощрения, наложения дисциплинарных взысканий и их учета в органах внутренних дел Российской Федерации // Тенденции развития науки и образования, 2020. № 67. Ч. 6. С. 118-121.

14. Жерлицын Б. И. Особенности дисциплинарного производства по советскому законодательству // Материалы IX конференции молодых ученых. - Минск, 1965. С. 2833.

15. Лебедев В. М. Воспитательная функция советского трудового права. - М., 1981.

16. Лейст О. Э. Санкция и ответственность по советскому праву. - М., 1981.

17. Лещина Э. Л. Совершенствование процессуальных основ служебной проверки в системе государственной службы Российской Федерации // Юридическая наука и правоохранительная практика. 2020. № 4 (54). С. 15 24.

18. Туганов Ю. Н. Правовое регулирование дисциплинарной ответственности военнослужащих при переходе Вооруженных сил Российской Федерации на контрактную систему комплектования: Дисс. ... канд. юрид. наук. - М., 2003.

\section{Бялт В.С., Чимаров С.Ю. \\ Юридическая ответственность: понятие и принципы}

Санкт-Петербургский университет МВД России (Россия, Санкт-Петербург)

doi: 10.18411/trnio-10-2021-117

\section{Аннотация}

В статье авторы исследуют вопросы, посвященные особенностям понимания категории «юридическая ответственность» в современной правовой науке. Анализируя мнения различных ученых правоведов, авторы обобщают и систематизируют теоретикоправовые знания в сфере понятия и принципов юридической ответственности, а также формулируют ряд выводов по рассматриваемой проблематике.

Ключевые слова: теория права, ответственность, юридическая ответственность, принципы юридической ответственности.

\section{Abstract}

In the article, the authors explore issues related to the peculiarities of understanding the category of "legal responsibility" in modern legal science. Analyzing the opinions of various legal scholars, the authors summarize and systematize theoretical and legal knowledge in the field of the concept and principles of legal responsibility, as well as formulate a number of conclusions on the issues under consideration.

Keywords: theory of law, responsibility, legal responsibility, principles of legal responsibility. 